\title{
Dynamics of Cell Migration from the Lateral Ganglionic Eminence in the Rat
}

\author{
J. A. De Carlos, L. López-Mascaraque, and F. Valverde \\ Laboratorio de Neuroanatomía Comparada, Instituto Cajal (CSIC), 28002 Madrid, Spain
}

From previous developmental studies, it has been proposed that the neurons of the ventrolateral cortex, including the primary olfactory cortex, differentiate from progenitor cells in the lateral ganglionic eminence. The objective of the present study was to test this hypothesis. The cells first generated in the forebrain of the rat migrate to the surface of the telencephalic vesicle by embryonic day (E) 12 . Using $\left[{ }^{3} \mathrm{H}\right]$ thymidine, we found that most of these cells contributed to the formation of the deep layer III of the primary olfactory cortex. To study the migratory routes of these cells, we made localized injections of the carbocyanine fluorescent tracers Dil and DiA into various parts of the lateral ganglionic eminence in living embryos at E12-E14 and subsequently maintained the embryos in a culture device for 17-48 hr. After fixation, most migrating cells were located at the surface of the telencephalic vesicle, whereas others were seen coursing tangentially into the preplate. Injections made at
E13 and in fixed tissue at E15 showed that migrating cells follow radial glial fibers extending from the ventricular zone of the lateral ganglionic eminence to the ventrolateral surface of the telencephalic vesicle. The spatial distribution of radial glial fibers was studied in Golgi preparations, and these observations provided further evidence of the existence of long glial fibers extending from the ventricular zone of the lateral ganglionic eminence to the ventrolateral cortex. We conclude that cells of the primary olfactory cortex derive from the lateral ganglionic eminence and that some early generated cells migrating from the lateral ganglionic eminence transgress the cortico-striatal boundary entering the preplate of the neocortical primordium.

Key words: cell migration; lateral ganglionic eminence; cortico-striatal sulcus; rat embryo culture; Golgi method; autoradiography; primary olfactory cortex
During embryonic development, migrating neurons reach their positions in the cortical layers following guidance cues provided by radial glial fibers (Rakic, 1971, 1972, 1985; Nowakowski and Rakic, 1979; Pinto-Lord et al., 1982; Gadisseux et al., 1990). In the dorsal and lateral parts of the telencephalic vesicles (TV), glial fibers course radially, whereas in more medial and lateral parts they follow curved, divergent trajectories (Gadisseux et al., 1989; Edwards et al., 1990; Misson et al., 1991). Retroviral lineage studies have shown that other cells move tangentially through the intermediate zone, resulting in widely separated groups of cells in the cortical plate (Luskin et al., 1988; Price and Thurlow, 1988; Walsh and Cepko, 1988, 1992; Austin and Cepko, 1990; O'Rourke et al., 1992, 1995; Reid et al., 1995). Cell dispersion was found to be extensive in the ventrolateral parts of the cerebral cortex (Austin and Cepko, 1990; Misson et al., 1991; Tan et al., 1995), probably because of the routes taken to follow the long radial glial fibers bordering the basal ganglia (Austin and Cepko, 1990; Walsh and Cepko, 1992).

During the early stages of development, the lateral wall of the TV forms a continuous semicircular sheet with no obvious regional specialization. The first evidence of differentiation is the ventrolateral appearance of a dome-shaped elevation protruding into the ventricular cavity. This elevation becomes divided by a sulcus into a lateral and a medial part known, respectively, as the

Received April 3, 1996; revised July 10, 1996; accepted July 15, 1996.

J.A.D., L.L.-M., and F.V. contributed equally to this work. This research was supported by Research Project PB91-0066 from the Ministerio de Educación y Ciencia of Spain. We are grateful to M. L. Poves for histological work and N. Salvador for animal facilities.

Correspondence should be addressed to Dr. Juan A. De Carlos, Instituto Cajal (CSIC), Avenida del Doctor Arce 37, 28002 Madrid, Spain.

Copyright (C) 1996 Society for Neuroscience $0270-6474 / 96 / 166146-11 \$ 05.00 / 0$ lateral (LGE) and medial (MGE) ganglionic eminences (Smart and Sturrock, 1979; Lammers et al., 1980). The sulcus separating the ganglionic eminences from the dorsal part of the TV (corticostriatal sulcus) represents the boundary separating two major compartments of the germinal zone. Dorsal to the sulcus, proliferating cells in the ventricular zone (VZ) will give rise to the laminated neocortex. Ventral to the sulcus, the ventricular and subventricular zones will produce cells destined to give rise to the striatum and possibly other paleocortical formations.

Studies using $\left[{ }^{3} \mathrm{H}\right]$ thymidine autoradiography demonstrated that cells in the primary olfactory cortex (POC) are among the first cortical neurons to differentiate (Hinds and Angevine, 1965; Smart and Smart, 1977; Bayer, 1986; Valverde and Santacana, 1994). Whether the POC arises from the VZ of the LGE or from the cortical neuroepithelium is still a matter of debate, and several questions have not yet been explained. (1) Where do the early generated cells of the POC come from? (2) Do they originate in the germinative neuroepithelium of the neocortex, in the basal ganglionic eminences, or in both? (3) Which are the routes taken by migrating cells to reach the ventrolateral cortex? To address these questions, we made use of autoradiographic sections to study the fate of early generated cells in the POC. We have followed the course of migratory cells from the ganglionic eminence by injecting carbocyanine dyes into embryos that were subsequently cultured in roller bottles. Finally, we have studied the arrangement of radial glial fibers in Golgi preparations to trace the pathways followed by early migrating cells.

\section{MATERIALS AND METHODS}

Animals. Wistar rats raised in the animal colony of the Cajal Institute were used in this study. Postnatal animals were obtained from timed 
pregnant rats. The day of insemination was defined as embryonic day (E) 0 , and the first $24 \mathrm{hr}$ after birth was defined as postnatal day (P) 0. Pups were born on E22 (P0). All animals were handled in a humane manner to avoid major distress and anesthetized with Equithesin $(3 \mathrm{ml} / \mathrm{kg}$ body weight).

Autoradiography. We have made use of our collection of autoradiographic material used in previous studies. In the present work, we examined animals injected at E12 and perfused at different times from 6 hr after injection to young adulthood. The details of our protocol and the identification of labeled cells have been published elsewhere (Valverde and Santacana, 1994; Valverde et al., 1995b). In short, pregnant rats of known gestational ages were injected intraperitoneally with 3-7 $\mu \mathrm{Ci} / \mathrm{gm}$ body weight of $\left[{ }^{3} \mathrm{H}\right]$ thymidine (Amersham, $\left[6-{ }^{3} \mathrm{H}\right]$ thymidine, specific activity $20-30 \mathrm{Ci} / \mathrm{mmol}$ ) and allowed to deliver normally. Offspring and older animals were perfused through the left ventricle with $10 \%$ formaldehyde in $0.1 \mathrm{M}$ phosphate buffer. After perfusion, the brains were embedded in paraplast and sectioned at $7-8 \mu \mathrm{m}$ in the frontal plane. Sections were mounted on gelatin-coated slides, dipped in Kodak NTB-2 or Ilford K5D emulsions, and stored in light-proof boxes at $4^{\circ} \mathrm{C}$ for 6 weeks. The slides were finally developed in D19 developer and stained with thionine before coverslipping.

A cell was considered positive (heavily labeled) when it contained more than one half the maximum number of silver particles found in the most heavily labeled cell. The evaluation of the number of silver grains was conducted using image processing software (Global Lab Image from Data Translation, Marlboro, MA). These criteria were not followed in obvious cases of heavy label but served to differentiate cells containing less silver grains. The reconstruction of the distribution of labeled cells was obtained with the aid of a computer-based reconstruction program (Design CAD 3-D, American Small Business Computers, Pryor, OK) working in overlay mode directly on microscope video images.

Golgi method. We have made use of our large collection of Golgistained preparations from the brains of rats sectioned in different planes and from distinct pre- and postnatal ages. In this study, we have selected embryonic material from E15 to E20, and young postnatal animals from P1 to P7. The material was stained by the rapid Golgi technique as described previously (Valverde, 1970, 1993).

Injection of fluorescent tracers and culture of whole embryos. To examine the migratory pathways of neurons generated in the VZ of the TV and in the ganglionic eminence, we injected live embryos from E12 to E14 with fluorescent carbocyanine tracers (Molecular Probes, Eugene, OR) (Honig and Hume, 1986, 1989). DiI and/or DiA dissolved in dimethylformamide $(0.5 \%)$ were injected through a fine-tipped crystal micropipette using a pressure system (Picospritzer, General Valve, Fairfield, NJ). The target areas were the ventrolateral part of the neocortical neuroepithelium, the sulcus between the neuroepithelium and the LGE, and the LGE. The majority of the embryos received a single injection of either DiI or DiA, but some embryos received two separate injections with DiI and DiA. Injections were performed at E12, E13, or E14, and embryos were subsequently cultured for different periods of time (see Table 1). Some embryos of different gestational ages (E12-E17) were removed, fixed, and labeled in vitro with tiny carbocyanine crystals placed in the appropriate structures to eliminate the possibility of transneuronal transport of the dye, the retrograde label of cells, and to study the pattern of radial glia.

The technique for dissecting, handling, and culturing embryos is based largely on the methods and protocols described by Cockroft (1990). Pregnant rats of known gestational ages were deeply anesthetized with Equithesin, and their uterine horns were exposed by a longitudinal

\begin{tabular}{lll}
\hline \multicolumn{2}{l}{ Table 1. Whole embryo cultures } & \\
Age & Animals & Survival time (hr) \\
\hline E12 & 14 & 24 \\
E12 & 8 & 48 \\
E13 & 5 & 17 \\
E13 & 2 & 22 \\
E13 & 9 & 24 \\
E14 & 2 & 19
\end{tabular}

Age, Age at the time of carbocyanine injection in the lateral ganglionic eminence area; Survival time, time of embryo culture in hours. abdominal incision. The embryos were dissected out individually in a petri dish containing Hank's balanced solution at $37^{\circ} \mathrm{C}$ using microscissors and a pair of watchmaker forceps under sterile conditions. The muscular uterine wall and the decidua were removed, and the Reichert's membrane was opened and dissected to reveal the vascularized visceral yolk sac and the embryo within it. The yolk sac was partially broken at its avascular site (around the junction with the placenta), maintaining the integrity of the vitelline arteries and veins but allowing the exposure of the embryo attached by the umbilical vessels, taking care not to cut into the chorioallantoic placenta. The amnion was removed and the vessels of the vitelline stalk were tucked under the tail of the embryo. The carbocyanine dyes were injected under a dissecting microscope, introducing the micropipette through the TV in a caudorostral orientation to approach the target structures from inside the ventricle. Although some tracers may contaminate the caudal neuroepithelium at the point where the micropipette enters the brain, this did not interfere with the intended labeling in the rostral TV. Neurogenesis in the cortex follows a rostrocaudal gradient and, at the time of the injections (E12, E13), the caudal brain is still an undifferentiated neuroepithelium where no labeled cells can be seen migrating longitudinally from caudal to rostral areas. Finally, the injected embryo was transferred to a glass bottle containing culture medium (see below).

To observe patterns of cell migration comparable to those occurring in normal animals, embryos were not cultured for more than $48 \mathrm{hr}$. The culture of rat embryos in vitro is very difficult and is only feasible during the period of early organogenesis. The success is probably related to the capacity of the yolk sac to grow in vitro because it provides a surface for nutritional and respiratory exchange between the embryo and the substrate. New (1990) reported that the success of in vitro culture depends on the stage of development. Thus, cultures initiated after the formation of the allantoic placenta result in embryos that are well formed but somewhat smaller. Embryo culture for more than $48 \mathrm{hr}$ results in severely impaired development.

Embryos were maintained in a culture device (BTC Engineering, London, UK) that consists of a hollow drum rotating at $30 \mathrm{rpm}$ housed in a $37^{\circ} \mathrm{C}$ incubator. The drum rotates around the horizontal axis and contains apertures to which culture bottles ( $15 \mathrm{ml}$ capacity) can be attached. The system allows continuous gassing $\left(95 \% \mathrm{O}_{2}, 5 \% \mathrm{CO}_{2}\right)$ of the culture bottles that are attached with hollow silicone bungs to the apertures of the rotating drum. The culture medium contained rat serum obtained by centrifugation of blood immediately after withdrawal from the donor animal, which was then heat-inactivated at $56^{\circ} \mathrm{C}$ for $40 \mathrm{~min}$. Each culture bottle was prepared with $4 \mathrm{ml}$ of serum and included 500 $\mu \mathrm{g} / \mathrm{ml}$ streptomycin with $2 \mathrm{mg} / \mathrm{ml}$ glucose. We put two embryos in each bottle, and their continued survival was monitored by the observation of their heartbeat. After culture, the head of each embryo was removed and fixed in $10 \%$ formalin in $0.1 \mathrm{M}$ phosphate buffer for $24 \mathrm{hr}$. Coronal serial vibratome sections were obtained at $100 \mu \mathrm{m}$ thickness. To identify the different structures, sections were counterstained with bisbenzimide (Sigma, St. Louis, MO). The slides were studied in a Nikon fluorescent microscope using the appropriate rhodamine $(560-610 \mathrm{~nm})$, fluorescein $(450-490 \mathrm{~nm})$, or ultraviolet $(330-380 \mathrm{~nm})$ filters to visualize DiI, DiA, and bisbenzimide, respectively.

\section{RESULTS}

\section{Fate of cells generated in the lateral wall of the TV during early phases of development}

To follow the origin and final position of early generated cells in the lateral wall of the TV, we analyzed autoradiographic sections approximately passing through the rostral one-third of the TV, corresponding to the level of the anterior commissure (AC) in the adult. In rats injected with tritiated thymidine at E12 and examined $6 \mathrm{hr}$ later (Fig. 1A), heavily labeled cells appear scattered throughout the VZ. These cells corresponded to cells in various phases of the mitotic cycle that had taken up the label and had not had sufficient time to dilute it. However, even at these early phases, an outer ring of nonradially orientated cells and processes can be distinguished. This outer ring was more prominent in the ventrolateral aspect, at the region bordering the ganglionic eminence. It contained heavily labeled cells that had completed their 

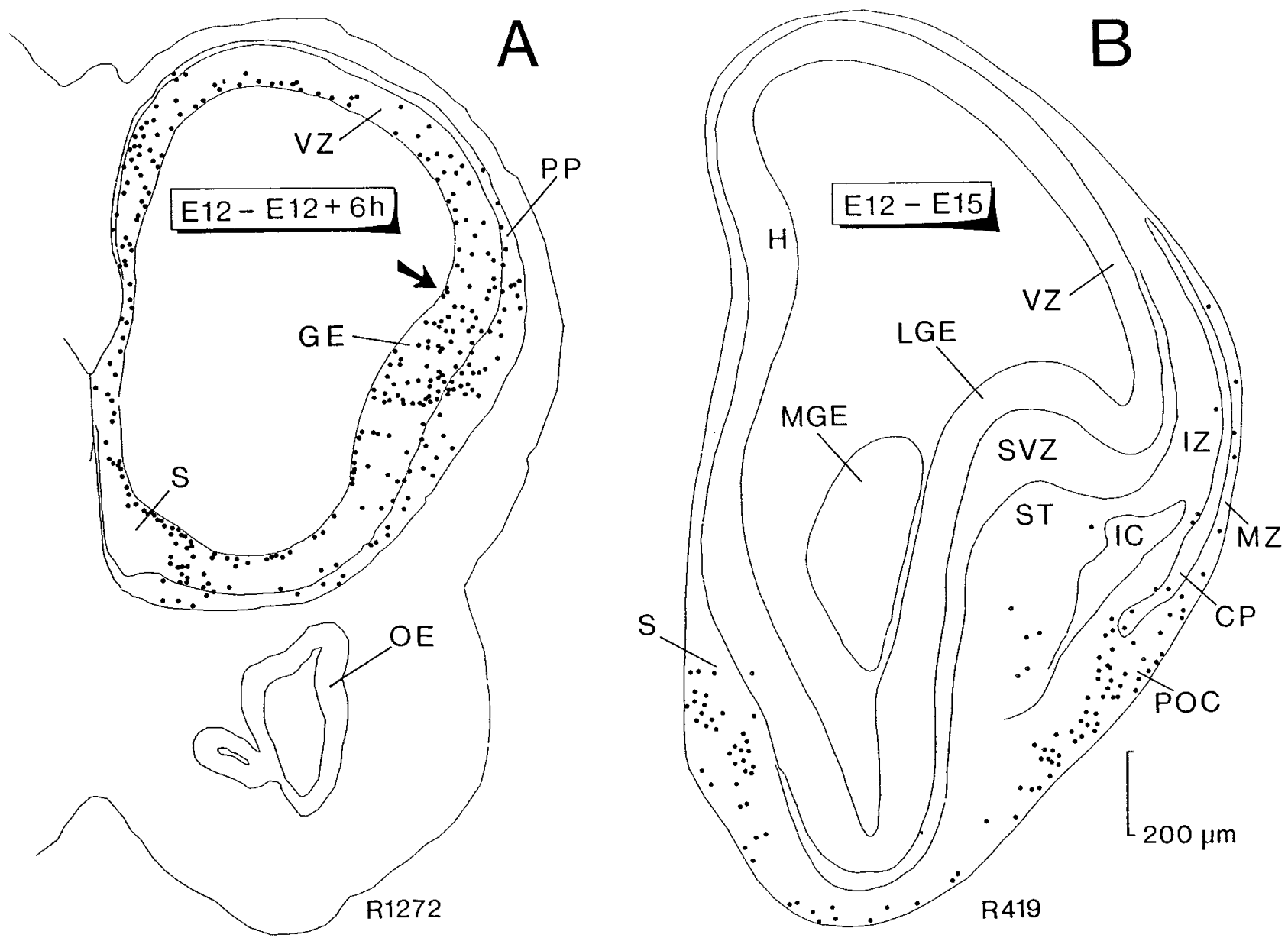

Figure 1. Computer printouts of the distribution of heavily labeled cells after $\left[{ }^{3} \mathrm{H}\right]$ thymidine injection at E12 and perfusion $6 \mathrm{hr}$ later $(A)$ and at E15 $(B)$. Transverse sections through the anterior part of the forebrain. In $A$, most labeled cells are located in the ventricular zone (VZ), corresponding to progenitor cells in various phases of the mitotic cycle or to migrating cells after completing their last division. Heavily labeled cells outside the VZ appear to be located in the surface in the ventrolateral part of the TV and in the emerging preplate $(P P)$. They correspond to the first-generated cells in the TV. The arrow points to the incipient cortico-striatal sulcus. In $B$, heavily labeled cells are distributed in several regions of the basal forebrain; numerous cells are concentrated in the septal area $(S)$, prospective primary olfactory cortex $(P O C)$, and basal forebrain. Scattered labeled cells are dispersed in the base of the striatum $(S T)$, the marginal zone $(M Z)$ bordering the incipient cortical plate $(C P)$, and below it in the intermediate zone $(I Z)$. Each dot represents one heavily labeled cell. Both printouts are reproduced at the same magnification. $G E$, Ganglionic eminence; $H$, differentiating hippocampal field; $I C$, internal capsule; $L G E$, lateral ganglionic eminence; $M G E$, medial ganglionic eminence; $O E$, olfactory epithelium; $S T$, striatum; $S V Z$, subventricular zone.

last mitotic division, settling in the neocortical preplate and in the ventrolateral part of the TV.

In rats injected with tritiated thymidine at E12 and examined at E15 (Fig. 1B), five distinct groups of cells were identified in the TV: (1) the septal group on the ventromedial side $(S)$; (2) a small number of labeled cells often arranged in discrete clusters in the ventral part of the prospective striatum $(S T)$; (3) cells in the marginal zone $(M Z)$ above the cortical plate $(C P)$, probably corresponding to Cajal-Retzius neurons; (4) cells in the intermediate zone (IZ) representing subplate cells destined to form the rodent layer VIb in the adult; and (5) a dense group of labeled cells located at the ventral tip of the cortical plate in a region corresponding to the prospective POC.

Rats injected at E12 and examined at P63 (Fig. 2) showed the adult distribution of the earliest generated cells, recorded in one frontal section at the level of the AC. Here, we observed most of the different groups recognized previously. Thus, the medial aspect of this section contained many labeled cells below the AC and septum (S), probably corresponding to the septal group of Figure $1 B$. Labeled cells were present in the ventral part of the $\mathrm{ST}$, in layer VIb (VIb), and in layer III of the POC below the compact layer II. No labeled cells were observed in layer I of the cortex.

Three sections have been chosen to exemplify the fate of early generated cells in the ventrolateral aspect of the forebrain (Figs. $1 A, B, 2)$. Although they illustrate the origin and final position of these cells, they are not entirely comparable. The expansion of the cerebral wall and its invagination and folding greatly alter the morphology of the forebrain during development. The ingrowth of the LGE within the ventricular cavity causes the ventricular pallial and striatal zones on both sides of the cortico-striatal sulcus to coalesce and blend into the most lateral parts. Thus, dashes of germinative neuroepithelium can always be recognized laterally bordering the ST during late embryonic development and the early postnatal period, probably as components of the subependymal layer around the anterior horn of the lateral ventricle (Alt- 


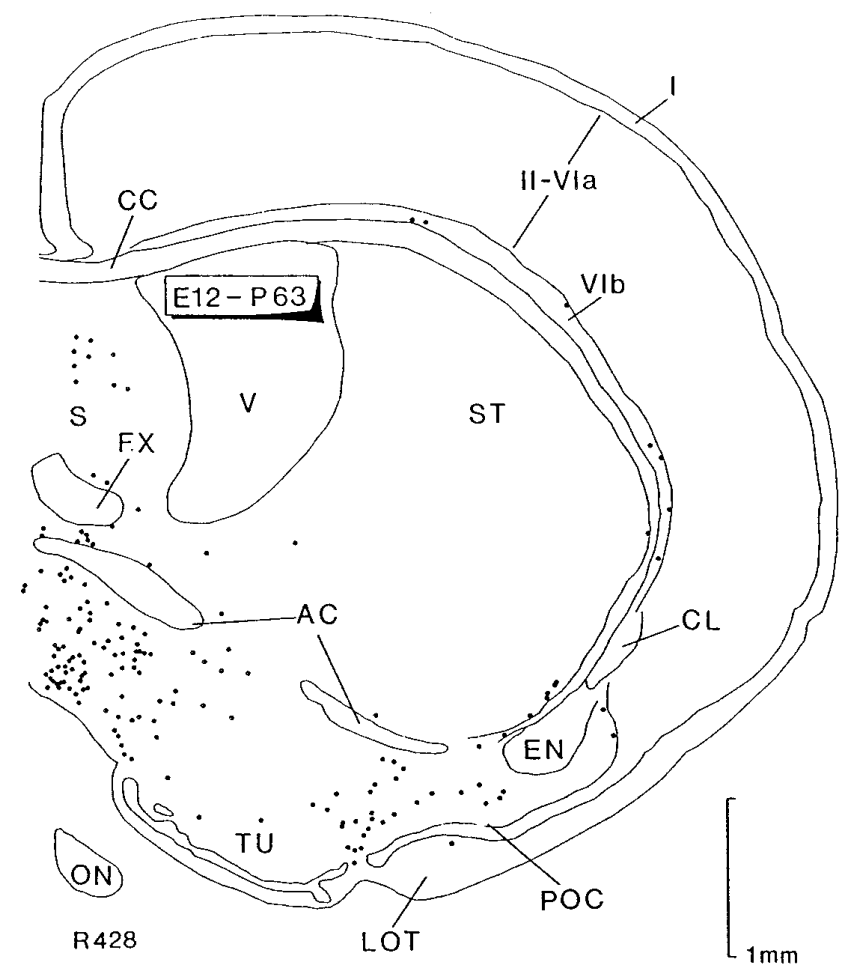

Figure 2. Computer printout of the distribution of heavily labeled cells after $\left[{ }^{3} \mathrm{H}\right]$ thymidine injection at E12 and perfusion at P63. Transverse section through the level of the anterior commissure. Cells in the deep part (layer III) of the primary olfactory cortex $(P O C)$ are heavily labeled. On the medial side, numerous labeled cells appear to be located in the septal area $(S)$ and below the anterior commissure $(A C)$. Scattered cells, some of them forming clusters containing heavily labeled cells (not seen in the figure), can be observed in the base of the striatum (ST). Labeled cells are present in sublayer VIb $(V I b)$, whereas no labeled cells were detected in the neocortical layer I $(I)$. These groups of labeled cells, except those in layer I, are homologous to the labeled groups represented in Figure $1 B$. Each dot represents one heavily labeled cell. $C C$, Corpus callosum; $C L$, claustrum; $E N$, endopiriform nucleus; $F X$, fornix; $L O T$, lateral olfactory tract; $O N$, optic nerve; $T U$, olfactory tubercle; $V$, lateral ventricle; $I I-V I a$, neocortical layers.

man, 1966; Stensaas and Gilson, 1972; lateral cortical stream of Bayer and Altman, 1991a). The result of these transformations is that early migrating cells reach the surface of the lateral TV directly, whereas late-generated cells must follow increasingly complex migratory routes.

\section{Pattern of migrating cells in cultured embryos}

To determine the pathways followed by cells destined for the ventrolateral cortex, during early neurogenesis we injected minute amounts of carbocyanine dyes into discrete areas of the LGE and the neighboring VZ of the prospective neocortex at E12, E13, and E14 and cultured the embryos for up to $48 \mathrm{hr}$. For the reasons explained in Materials and Methods, embryos were not cultured for more than $48 \mathrm{hr}$, and therefore our descriptions are restricted to observations made during the early phases of migration. Carbocyanine-labeled migrating cells reveal morphological features typical of migrating neurons as described elsewhere (Rakic, 1972; Hatten, 1990; O’Rourke et al., 1992, 1995; Luskin, 1993). They adopt a bipolar morphology with a short and stout leading process (often ending in an enlarged growth cone) and a longer trailing process (e.g., Fig. 3B,D). Migrating labeled cells in living tissue appeared less membranous than those observed in fixed preparations because portions of the external membrane become sequestered into endocytic vesicles. Thus, the cells display an increasingly granular aspect and more faint membrane labeling with longer survival time (Honig and Hume, 1986; Honig, 1993). In our studies, isolated cells showing this characteristic morphology as well as bright punctate cytoplasmic labeling were considered indicative of live migrating cells that had moved away from the injection site.

Migrating cells, after injections made into the core of the LGE (Fig. $3 A$ ) or in the cortico-striatal sulcus (Fig. 3C), were located to the lateral surface of the TV (Fig. $3 B$ ) or followed a ventral pathway (Fig. $3 C$, arrow). Figure $3 D$ is an enlarged photomicrograph of the two migrating cells indicated by an arrow in Figure $3 C$. These cells were probably migrating toward the basal telencephalon (BT) to eventually reach the prospective POC. We observed that injections made in the cortico-striatal sulcus or in the core of the LGE always gave rise to the formation of a patch of bright labeling at the surface of the TV in front of the implantation site (Fig. 3C,E, arrowheads). These patches contain the bulk of the labeled neurons with processes that had migrated away from the injection site, as well as radial glial fibers. Most cells appeared heavily labeled, but other cells had the characteristic faint labeling and punctate appearance of migrating elements as seen in Figure $3 F$ (arrow). The distance traveled by these cells increases with longer survival times, which in this example (an embryo cultured for $48 \mathrm{hr}$ ) is particularly significant because of the long distance traveled by the cell, the location of which is marked by a solid arrow in Figure $3 E$. Similarly, after injections made at the surface of the basal part of the TV, migrating cells running dorsally to reach the neocortical marginal zone were observed (Fig. 3G, arrow).

Migrating cells in the marginal zone were orientated tangentially. These cells probably reached the preplate at the surface of the TV following radial glial fibers and later turned at right angles to run tangentially under the pial surface.

An unexpected finding was that pairs of migrating neurons occasionally looked as if they had crossed each other or diverged in opposite directions after reaching the marginal zone (Fig. 3B). This observation should be taken with caution because of the lack of a distinct polarity in some cases. In our experiments, longdistance migrating cells that coursed dorsally predominate when the injections were made into the core of the LGE (Fig. $3 A, E$ ) or at the surface of the ventrolateral part of the TV (Fig. $3 G$ ). However, as described above, migrating cells running ventrally were also noted after depositing dye in the cortico-striatal sulcus (Fig. 3C). In this case (an embryo injected at E13 and cultured for $17 \mathrm{hr}$ ), it is possible that these migrating cells followed long and curved radial glial fibers stretching from the ventricular angle to the prospective POC (see below). After injections at the ventricular surface of the LGE at E12 and the culture of embryos for 48 hr (Fig. 4), groups of migrating cells were detected, apparently following these glial fibers to reach the prospective POC (Fig. $4 A$ ). However, some migrating cells that arrived at the ventrolateral surface of the TV did not settle in the POC but continued to migrate dorsally toward the preplate, adopting a tangential orientation. In the course of this migration, some cells adopted a vertical orientation, probably indicating their arrival at their final destination (Fig. 4C). 

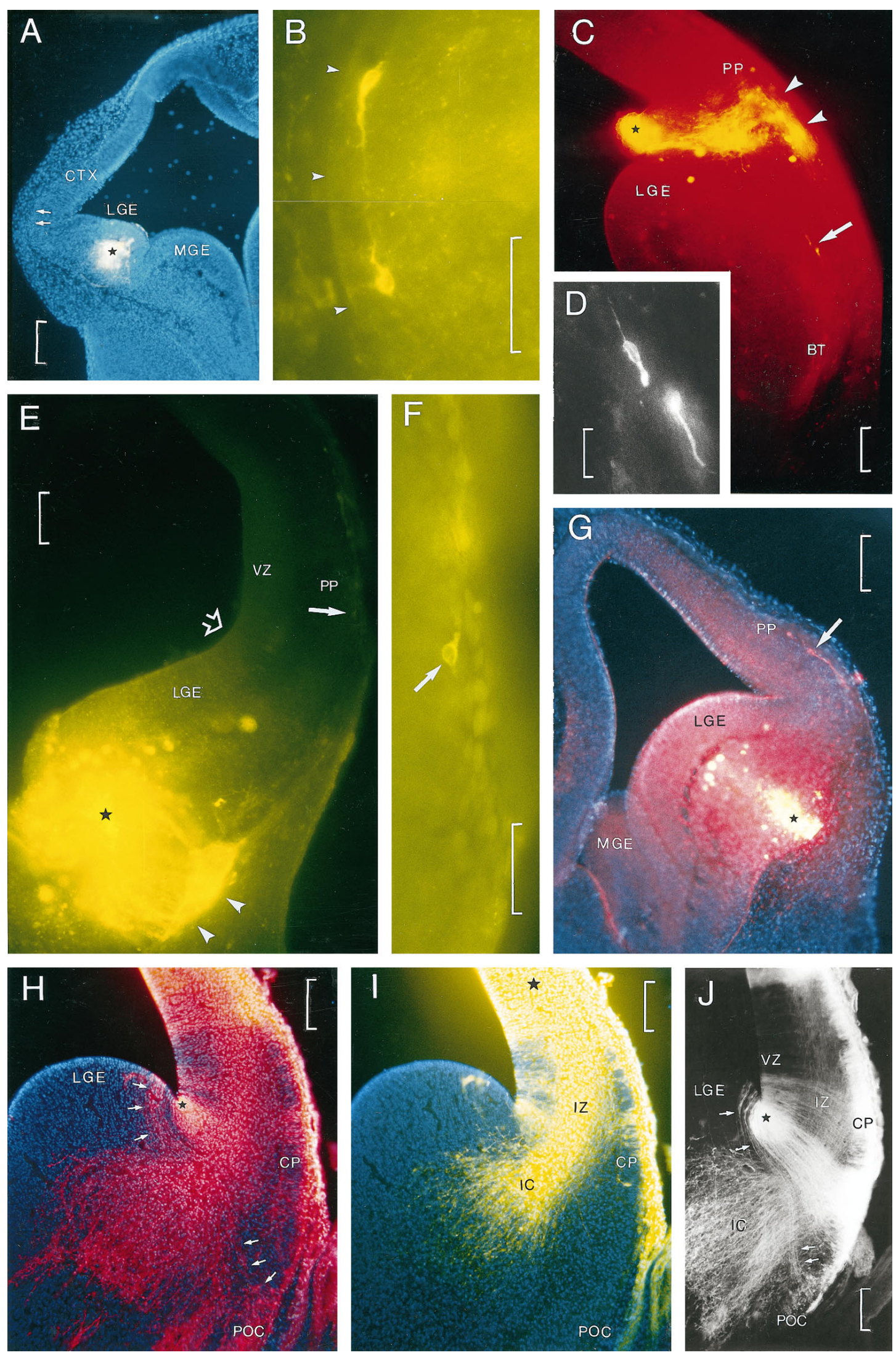

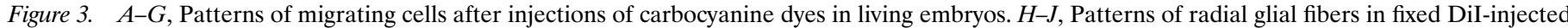

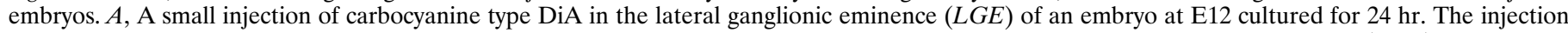
site is marked by a star, and the section was counterstained with bisbenzimide. The two arrows in the lateral border of the cortex $(C T X)$ point to two

(Figure legend continues) 


\section{Labeling of fixed embryos}

Several fixed embryos from E12 to E17 were labeled with DiI and/or DiA in the LGE, as well as in the VZ of the cortical neuroepithelium, close to the cortico-striatal sulcus.

Labeling in the $\mathrm{VZ}$ of the LGE at E12 revealed a columnar organization of cells mixed with very immature radial glial cells that were sending their processes toward the surface of the TV. Labeling of the same structure at E13 and E14 showed the same columnar organization of cells mixed with apparently mature radial glial cells. At the surface of the TV, some cells were seen adopting a tangential orientation. These cells probably had been released from radial glial cells. Labeling in the VZ of the cortical neuroepithelium showed the same columnar organization. Injections at E15 and onward showed intense labeling of fibers: radial glial fibers in the LGE and fibers belonging to the internal capsule, which begin to form at E14. E15 is a good stage to study the shape and pattern of the radial glia. As such, deposits of different carbocyanine dyes placed in the cortico-striatal sulcus and in the cortical neuroepithelium at E15 labeled a group of radial glial cells coursing from the VZ of the LGE to the prospective POC (Fig. 3H,J, arrows) and fibers of the internal capsule reaching the midpoint of the prospective ST. These glial fibers followed an S-shaped curvature with their endfeet at the pial surface in the zone corresponding to the prospective POC. They were traversed by fibers of the internal capsule (Fig. 3H,I,J) so that migration through this complex lattice may be considerably impeded.

From the observations in cultured embryos after injections close to the cortico-striatal sulcus (Figs. 3C,D, 4) and the trajectory of radial glial fibers observed in fixed material (Fig. $3 H, I, J$ ), we conclude that the $\mathrm{VZ}$ of the ganglionic eminence is likely to be the source of neurons for the basolateral part of the TV, including the olfactory cortex (Fig. 4C).

\section{Observations made in Golgi preparations}

Given the convex nature of the TV, glial fibers appear to be orientated roughly perpendicular to the pial surface, but those that originated close to the lateral ventricular angle or in the ganglionic eminences follow a curved trajectory that is best illustrated in Golgi preparations. Frontal sections of embryos at E15 (Fig. 5) showed the curved trajectory of radial glia from the lateral part of the ganglionic eminence to the region of the POC. Defective impregnation in this preparation did not allow us to observe the full extension of radial glial fibers; however, their trajectory was reminiscent of the S-shaped trajectory described above at the same embryonic age (compare Fig. $3 H, J$ with Fig. 4). This pointto-point relationship between the ganglionic eminence and the POC appeared more evident in frontal sections, slightly inclined to the transverse plane, as seen in Figure 6. This section corresponds to an embryo at E18 that was cut with a slant of $\sim 30^{\circ}$ with respect to the transverse plane, so that the lateral part is anterior with respect to the medial side. It allowed us to visualize the entire span of radial glial fibers from the ventricular surface to the POC. Note that glial fibers from the vertex of the lateral ventricular angle could be traced to an area in the cerebral wall above the POC (arrow). This zone corresponds approximately to the limits between the agranular insular and gustatory areas and somatosensory cortices of the adult.

At early postnatal ages (Fig. 7; $2 \mathrm{~d}$ postnatal), the system of radial glial fibers appeared to be completely developed. Glial fibers arising in the lateral ventricular angle arc laterally following in part the lateral border of the ST to end at the level of the sulcus rhinalis and above. However, the cut ends of glial fibers spanning across the POC (Fig. 7, arrows) could only be traced to the striatal $\mathrm{VZ}$ at a region corresponding to the level marked by arrowheads in more anterior adjacent sections. These observations confirmed that radial glial fibers spanning laterally to the ventrolateral parts of the cerebral cortex have their corresponding cell bodies located in the striatal $\mathrm{VZ}$ and not in the lateral ventricular angle.

\section{DISCUSSION}

Two main findings have emerged from the present study. (1) Cells from the LGE migrate to the surface of the cortex to reach the marginal zone, where they run tangentially for variable distances. (2) Radial glial cells from the LGE provide the pathway for migrating cells to arrive at the lateral and basolateral parts of the cortex, including the POC.

\section{Cell migrations from the LGE and lateral ventricular edge}

According to our autoradiographic studies (Valverde and Santacana, 1994; present observations), it is possible that cells born at E12 in the VZ of the LGE migrate to the ventrolateral part of the $\mathrm{TV}$, where they contribute to the formation of the POC. Cell birthdating cannot by itself define whether cells in the POC come

\section{$\leftarrow$}

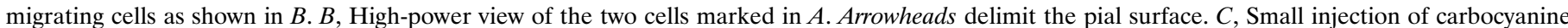

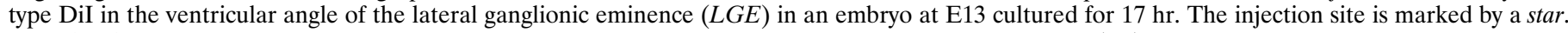

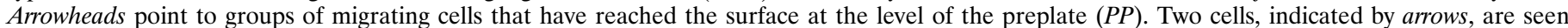

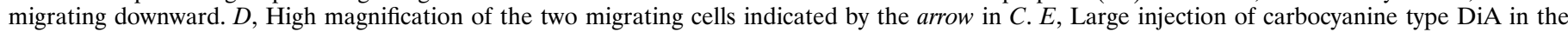

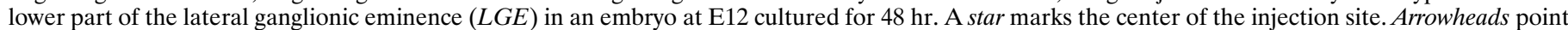

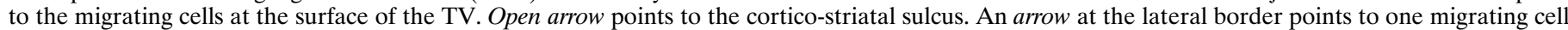

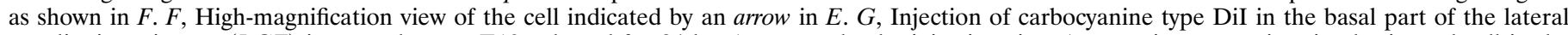

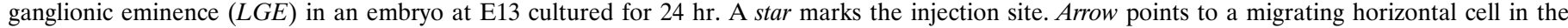

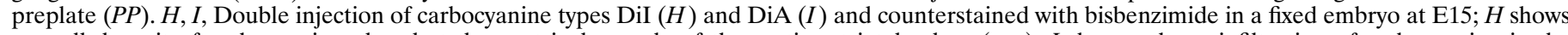

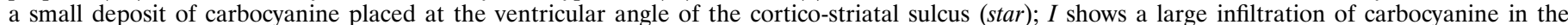

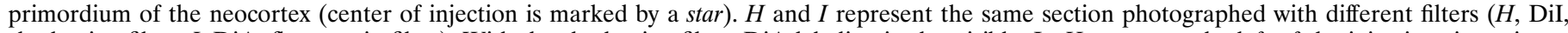

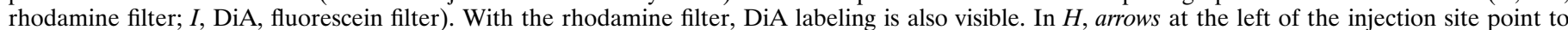

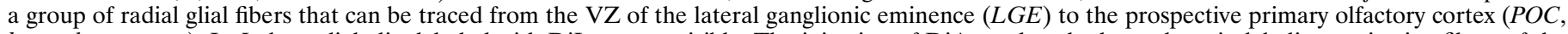

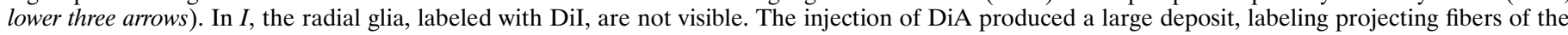

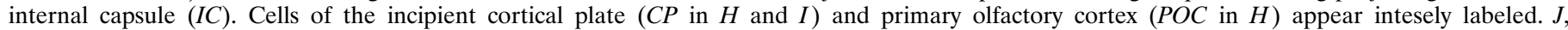

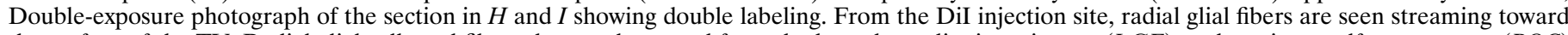

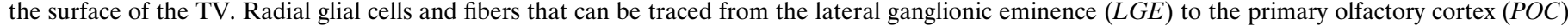

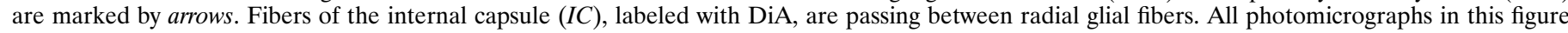

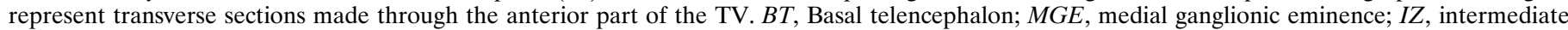
zone; $V Z$, ventricular zone. Scale bars: $200 \mu \mathrm{m}$ in $A, G$, and $J ; 50 \mu \mathrm{m}$ in $B$ and $F$; $100 \mu \mathrm{m}$ in $C, E, H$, and $I$; and $20 \mu \mathrm{m}$ in $D$. 

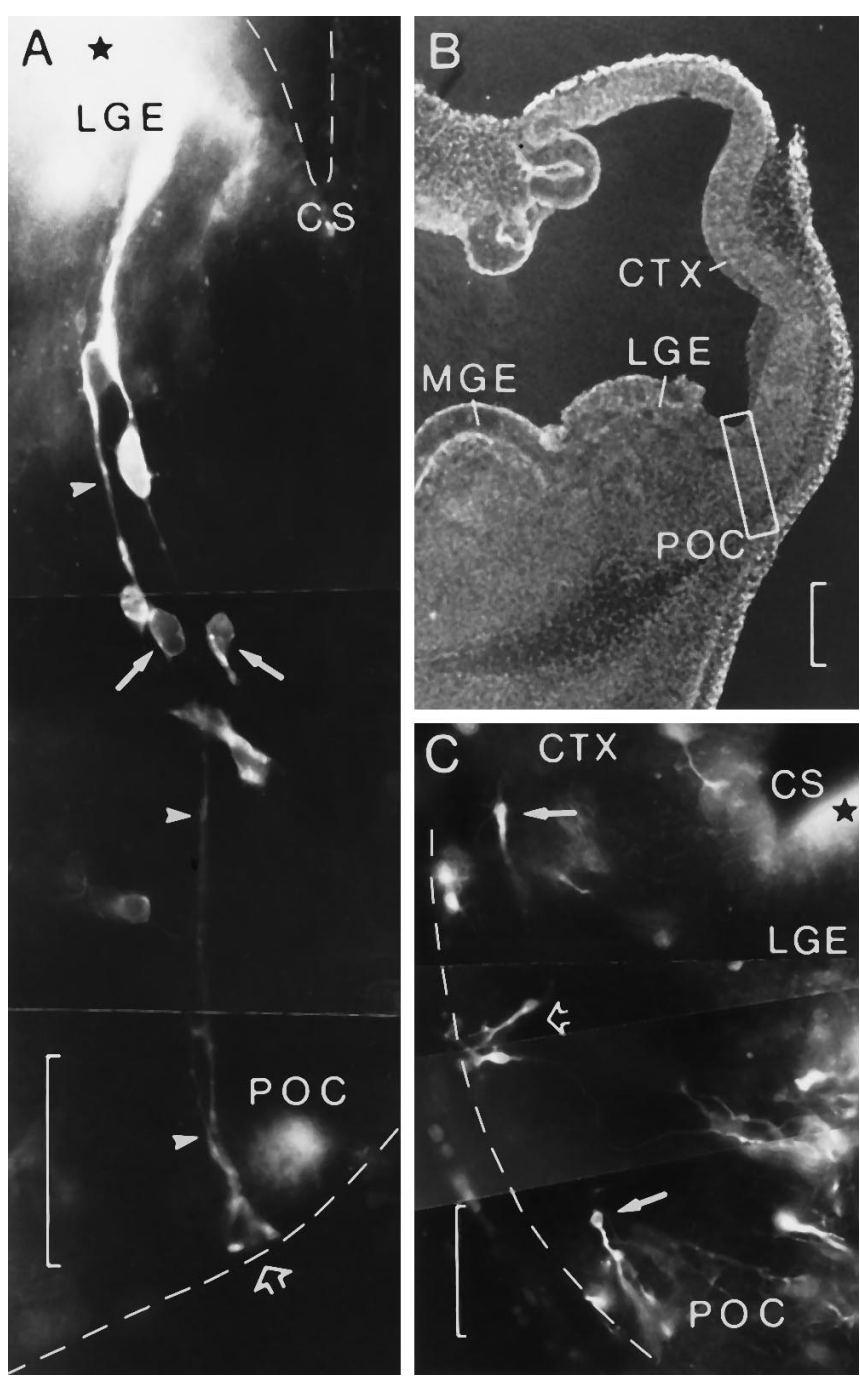

Figure 4. Small injections of carbocyanine type DiI in two embryos at E12 cultured for $48 \mathrm{hr}$. $A$, Transverse section showing the injection site (star) in the lateral ganglionic eminence ( $L G E)$ close to the cortico-striatal sulcus $(C S)$. Radial glial fibers (arrowheads) can be followed to where they form their endfeet at the pial surface (open arrow) in a region corresponding to the prospective primary olfactory cortex $(P O C)$. Several cells appear to migrate along glial fibers. Note the bright endocytic vesicles in the two migrating cells (arrows). B, Low-power view of the adjacent section. Boxed area delimits approximately the zone reproduced in $A$, medial being to the left. $C$, Transverse section through the right TV in another embryo showing a small injection site (star) in the ventricular surface of the lateral ganglionic eminence ( $L G E$ ) close to the cortico-striatal sulcus $(C S)$. After culturing for $48 \mathrm{hr}$, migrating cells appear to have reached the surface at the ventrolateral side of the TV, adopting tangential (arrows) and vertical (open arrow) directions. Medial is to the right. CTX, Neocortical primordium; $M G E$, medial ganglionic eminence. Scale bars: $50 \mu \mathrm{m}$ in $A$ and $C$; $200 \mu \mathrm{m}$ in $B$.

from the germinal epithelium of the neocortex or the LGE because at E12, after short survival times, there are labeled cells in both proliferative zones (see Fig. $1 A$ ). However, the observation of cells labeled in the preplate provides good evidence that they probably arise in the LGE, because $6 \mathrm{hr}$ probably would not be sufficient time for them to complete S-phase, divide, and migrate from the neocortical VZ. The unexpected data shown in Figure $1 B$, in which no labeled cells were observed in the dorsal neocortex after $3 \mathrm{~d}$ survival, can be explained by the fact that this section

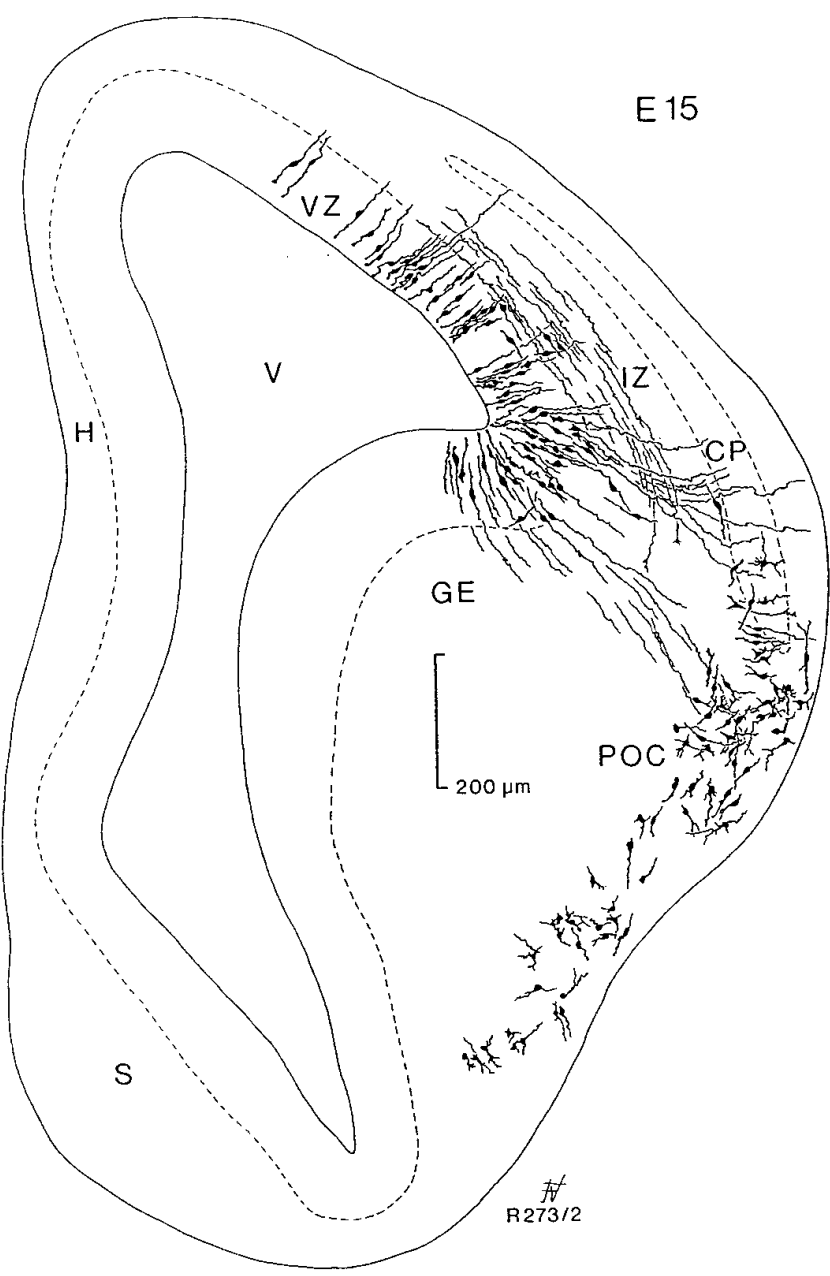

Figure 5. Camera lucida drawing of a transverse section passing through the anterior part of the forebrain vesicle stained by the Golgi method in an embryo of $15 \mathrm{~d}$. Staining is almost absent on the medial side. The lateral part shows radial glial cells of the ventricular zone $(V Z)$ coursing perpendicular to the surface. Migrating horizontal cells can be seen in the intermediate zone $(I Z)$ below the cortical plate $(C P)$. From the ganglionic eminence $(G E)$, glial fibers extend to the prospective primary olfactory cortex $(P O C)$, where numerous cells were stained. $H$, Differentiating hippocampal field; $S$, septal area; $V$, lateral ventricle.

is somewhat tangential and that the dorsal aspect is rather posterior, and thus too young to contain labeled neocortical preplate cells. This is in agreement with the findings shown in Figure 2 (frontal section), in which labeled cells in the subplate could be observed.

Our fluorescent tracer labeling of developing cells followed by short-term whole embryo culture showed that cells from the ganglionic eminence migrate to the surface of the TV. These cells may reach the pial surface and turn sharply at right angles to run tangentially in the preplate. Most migrating neurons showed faint overall labeling with strong punctate hot spots within the cytoplasm, typical of migrating living cells (Honig, 1993).

As described in other brain areas, tangential migration may occur along preexisting axonal pathways (Rakic, 1985, 1990; Gray et al., 1990), and most tangential migrations have been described in the IZ, which is rich in axons (Valverde et al., 1989; O'Rourke et al., 1995). In this case, the substratum may be provided by the 


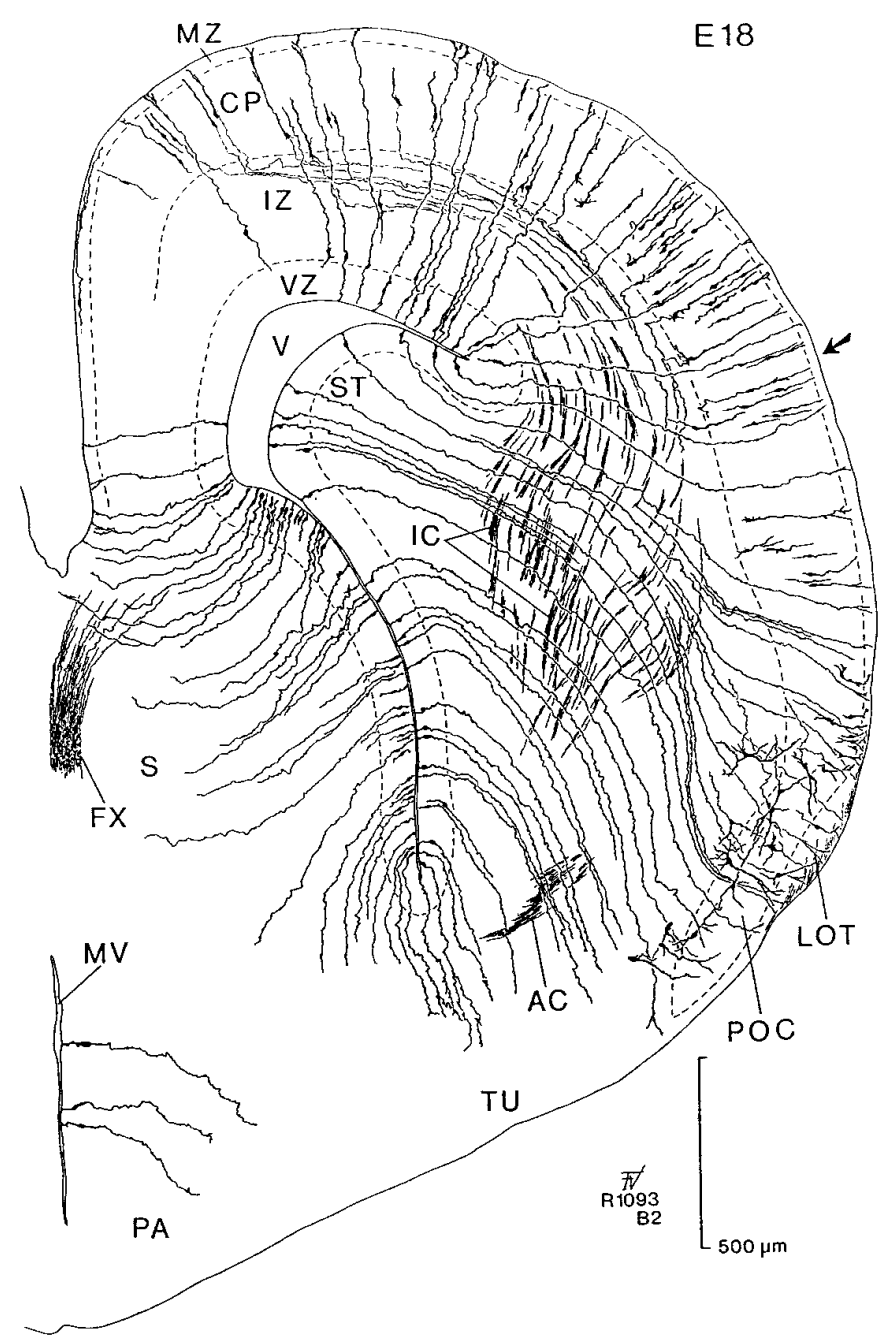

Figure 6. Camera lucida drawing of a transverse section stained by the Golgi method in an embryo of $18 \mathrm{~d}$. This brain was sectioned at an angle to the transverse plane so that the lateral part (right side) is anterior with respect to the medial part (left side, see Fig. 7C). Radial glial fibers extend from the ventricular zone $(V Z)$ to the surface of the brain. Cells of the emerging cortical plate $(C P)$ send axons through the intermediate zone (IZ) that enter the internal capsule $(I C)$. The tilt of these sections allows us to follow radial glial fibers from the $\mathrm{VZ}$ of the striatal primordium $(S T)$ to the primary olfactory cortex $(P O C)$. Note that radial glia from the lateral ventricular angle can be traced to a level in the cortex (indicated by an arrow). $A C$, Anterior commissure; $F X$, fornix; $L O T$, lateral olfactory tract; $M V$, third ventricle; $M Z$, marginal zone; $P A$, preoptic area; $S$, septum; $T U$, olfactory tubercle; $V$, lateral ventricle.

plexus of horizontal processes of the preplate (Valverde et al., 1995a). The presence of certain extracellular matrix components among the earliest postmitotic preplate neurons (Stewart and Pearlman, 1987) might also influence this tangential migration.

From E14 onward, the system of radial glial fibers is well developed, and migrating neurons appear to travel along these glial processes (Rakic, 1971, 1972, 1985; Nowakowski and Rakic, 1979; Pinto-Lord et al., 1982). In the ventrolateral parts of the TV, glial fibers arc in S-shaped trajectories, bordering the contours of the ST, and some cells that we found migrating along these glial fibers belong to this category. These curved glial fibers provide a possible substratum for tangential migrations (Gadisseux et al.,

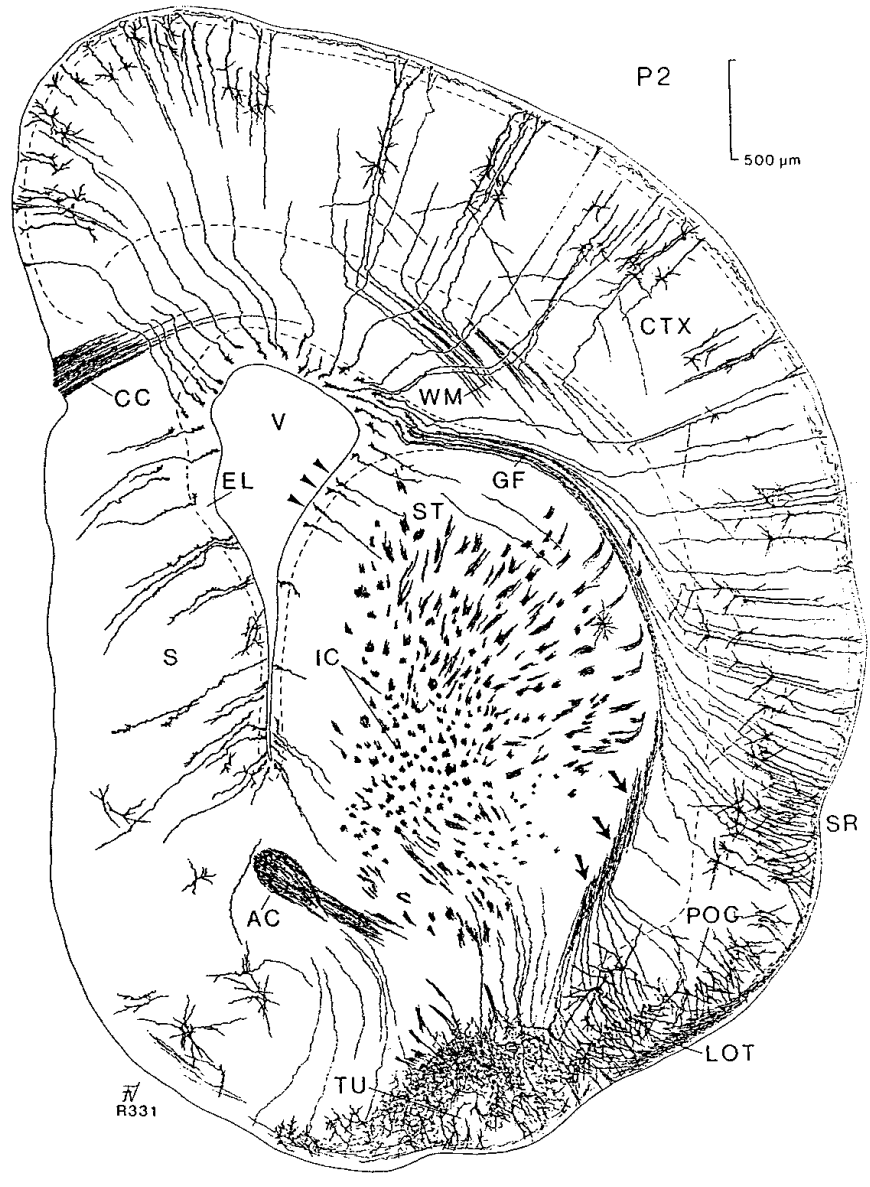

Figure 7. Camera lucida drawing of a transverse section stained using the Golgi method at postnatal day 2 at the level of the AC. This section shows young cortical cells with axons projecting to the white matter $(W M)$. Radial glial cells extend from the surface of the lateral ventricle $(V)$ to the cortex $(C T X)$ following diverse trajectories; glial fibers $(G F)$ from the lateral ventricular angle can be traced to the cortex above the sulcus rhinalis $(S R)$. A compact bundle of radial glial fibers (arrows) is located on the lateral side of the striatum $(S T)$. These fibers spread in a fantail manner when they traverse through the primary olfactory cortex (POC). Unlike the remaining glial fibers, they are not in the same plane; the continuity of the cut ends (indicated by arrows) was followed to the bodies of the glial cells (arrowheads) at the lateral border of the lateral ventricle after reconstruction in the two subsequent anterior sections. $A C$, Anterior commissure; $C C$, corpus callosum; $E L$, ependymal layer; $I C$, internal capsule; $L O T$, lateral olfactory tract; $T U$, olfactory tubercle.

1989, 1990; Misson et al., 1991; O’Rourke et al., 1995) and explain the lateral dispersion of clonally related cells in lateral cortical regions (Price and Thurlow, 1988; Austin and Cepko, 1990; Walsh and Cepko, 1992; Tan et al., 1995).

\section{The ventrolateral cortex derives from the LGE}

The idea that portions of the ventrolateral cortex derive from ventricular cells of the ganglionic eminences is not entirely new. According to Stensaas and Gilson (1972), proliferating cells close to the cortico-striatal sulcus migrate to lateral pallial regions. Smart and Smart (1977) suggested that the ganglionic eminence produces cells that will eventually be incorporated into the olfactory cortex. Smart and Sturrock (1979) demonstrated the presence in Golgi preparations of glial processes extending from the neostriatal primordium to the ventrolateral cortex, suggesting the cortical resemblance of the dorsal part of the LGE. More recently, 
Bayer (1990) regarded the piriform cortex as being derived from the LGE, and Bayer and Altman (1991b) considered that the neuroepithelium of the lateral ventricular angle may be classified as a cortical primordium. Halliday and Cepko (1992) also raised the possibility that some generative cells of the ST migrate to positions outside the ST. Interestingly, hybridization for Brn-4, one of the members of the family POU domain genes (Mathis et al., 1992), reveals migratory cells streaming out of the striatal primordium to form a layered structure in the ventrolateral surface of the TV, probably corresponding to the olfactory cortex [Alvarez-Bolado et al. (1995), their Fig. 11C].

Like following the thread of Ariadne, young neurons located at the surface of the TV can be tracked back to their point of origin in the VZ by tracing the course of neighboring glial fibers. Thus, as suggested by Nieuwenhuys (1972), the spatial organization of the radial glial system provides a coordinate system for the pathways of migrating neurons (Rakic, 1972, 1988; Schmechel and Rakic, 1979). In the present study, injections of carbocyanine dyes in the $\mathrm{VZ}$ of the LGE revealed the presence of migrating cells following long radial glial fibers that correspond to those we have studied in Golgi preparations. Thus, our Golgi observations demonstrated the existence of glial fibers extending from the $\mathrm{VZ}$ of the LGE to the ventrobasal cortex, including the POC. These observations were made possible by careful reconstruction of the complete course of glial fibers in transverse sections that were inclined in relation to the vertical axis. From these observations, we conclude that cells of the POC, and possibly other neuronal groups along the ventrolateral part of the cortex (periamygdaloid and perirhinal), derive from the LGE.

\section{The cortico-striatal sulcus: A major boundary domain?}

The sulcus separating the ganglionic eminences from the remaining dorsal part of the TV (the cortico-striatal sulcus) has been considered a major boundary separating the neocortical primordium from the BT. Tangential migrating cortical cells will not cross this border (Fishell et al., 1993) and, in spite of a certain heterogeneity among neuronal precursors, neurons generated on each side of the sulcus apparently remain in their own compartments (Johnston et al., 1991; Krushel et al., 1993). Strong calbindin-immunoreactive fibers appear to form a sharp limit between the pallial epithelium and the striatal anlage (Liu and Graybiel, 1992). In the same way, the cortico-striatal sulcus is delimited by the telencephalic expression of the Dlx homeotic gene (Bulfone et al., 1993), further evidence at the molecular level of the compartmentalization of this region (Price et al., 1991; Puelles and Rubenstein, 1993; Porteus et al., 1994; AlvarezBolado et al., 1995). Cells derived from the LGE of the rat embryo transplanted into the ST of adult rats developed exclusively striatal phenotypes (Deacon et al., 1994). However, cells from the striatal VZ transplanted at E15 to a cortical environment develop morphologies typical of pyramidal or stellate cortical cells (Fishell, 1995). In the present study, we found that cells from the LGE not only migrated radially to the ventrolateral surface of the $\mathrm{TV}$, but that other cells also traveled long distances, coursing tangentially into the preplate of the neocortical primordium. These observations indicate that cells are able to transgress the cortico-striatal boundary at early stages of development.

\section{Conclusion}

In summary, although our results are not absolutely conclusive, the three lines of evidence obtained using different approaches point strongly to the same conclusions. Thus, we propose the following developmental scheme for the behavior of cells derived from the LGE. Beginning at E12, the VZ of the LGE generates a first wave of neurons that move unaided (we presume that they move unaided because of the immaturity of radial glial cells at this age) toward the surface of the TV. Most of these cells remain at the surface of the TV and form part of the early generated cells (layer III in the adult) of the POC and possibly other olfactory cortical regions (Derer et al., 1977; Smart and Smart, 1977; Bayer, 1986, 1990; Bayer and Altman, 1991b; Bayer et al., 1991; Valverde and Santacana, 1994). The remainder of these cells migrate tangentially in the preplate (present results) and probably integrate into the preplate and emerging MZ as Cajal-Retzius cells (Valverde et al., 1995a). At E13-E14, radial glial fibers develop, supporting cell migration (Misson et al., 1988; Edwards et al., 1990; Liu and Graybiel, 1992). Cells generated in the VZ of the LGE migrate via these glial fibers, reaching layer II of the POC. Around this time, a second proliferative region, the subventricular zone, emerges in the neostriatal primordium (Smart, 1976; Smart and Sturrock, 1979). This zone increases in size considerably, forming a major site of mitotic activity that apparently supersedes the generation of cells in the VZ, but where the resulting neurons remain confined to the subventricular zone, to form the adult ST (Smart, 1976; Smart and Sturrock, 1979; Lammers et al., 1980; Fentress et al., 1981; Bayer, 1984; Halliday and Cepko, 1992). It is also possible that the increasing complexity of radial glial fibers forms a sharp lateral border (Liu and Graybiel, 1992) and that developing fibers of the internal capsule from E14 (De Carlos and O'Leary, 1992) form a barrier that obstructs cell migration.

From E15 onward, the development of the ST further displaces radial glial fibers that originated in the striatal VZ (Smart and Sturrock, 1979; Gadisseux et al., 1989; Misson et al., 1991). The glial fascicles remain packed, following an oblique concave surface (present observations). Most superficial cells of the POC generated at E15-E16 (Bayer, 1986) are still on their way to layer II of the POC. The long journey through these glial fibers explains the delayed arrival and settling of these neurons in the ventrolateral cortical areas (Bayer and Altman, 1991b; Bayer et al., 1991; Misson et al., 1991). Finally, although neurogenesis is largely completed in the ST by E19-E21 (Sidman and Angevine, 1962; Angevine and McConnell, 1974; Smart and Sturrock, 1979; Bayer, 1984), portions of the subventricular zone still continue to be mitotically active, giving rise to cells that migrate to the olfactory bulb (Altman and Das, 1966; Kishi, 1987; Kishi et al., 1990; Luskin, 1993).

\section{REFERENCES}

Altman JB (1966) Proliferation and migration of undifferentiated precursor cells in the rat during postnatal gliogenesis. Exp Neurol 16:263-278.

Altman J, Das GD (1966) Autoradiographic and histological studies of postnatal neurogenesis. I. A longitudinal investigation of the kinetics, migration and transformation of cells incorporating tritiated thymidine in neonate rats, with special reference to postnatal neurogenesis in some brain regions. J Comp Neurol 127:337-390.

Alvarez-Bolado G, Rosenfeld MG, Swanson LW (1995) Model of forebrain regionalization based on spatiotemporal patterns of POU-III homeobox gene expression, birthdates, and morphological features. J Comp Neurol 355:237-295.

Angevine JB, McConnell JA (1974) Time of origin of striatal neurons in the mouse. Anat Rec 178:300.

Austin CP, Cepko CL (1990) Cellular migration patterns in the developing mouse cerebral cortex. Development 110:713-732.

Bayer SA (1984) Neurogenesis in the rat neostriatum. Int J Dev Neurosci 2:163-175. 
Bayer SA (1986) Neurogenesis in the rat primary olfactory cortex. Int J Neurosci 4:251-271.

Bayer SA (1990) Development of the lateral and medial limbic cortices in the rat in relation to cortical phylogeny. Exp Neurol 107:118-131.

Bayer SA, Altman J (1991a) Neocortical development. New York: Raven.

Bayer SA, Altman J (1991b) Development of the endopiriform nucleus and the claustrum in the rat brain. Neuroscience 45:391-412.

Bayer SA, Altman J, Russo RJ, Dai X, Simmons JA (1991) Cell migration in the rat embryonic neocortex. J Comp Neurol 307:499-516.

Bulfone A, Puelles L, Porteus MH, Frohman MA, Martin GR, Rubenstein JLR (1993) Spatially restricted expression of Dlx-1, Dlx-2 (Tes1), Gbx-2 and Wnt-3 in the embryonic day 12.5 mouse forebrain defines potential transverse and longitudinal segmental boundaries. J Neurosci 13:3155-3172.

Cockroft DL (1990) Dissection and culture of postimplantation embryos. In: Postimplantation mammalian embryos. A practical approach (Copp AJ, Cockroft DL, eds), pp 15-40. New York: Oxford UP.

Deacon TW, Pakzaban P, Isacson O (1994) The lateral ganglionic eminence is the origin of cells committed to striatal phenotypes: neural transplantation and developmental evidence. Brain Res 668:211-219.

De Carlos JA, O'Leary DDM (1992) Growth and targeting of subplate axons and establishment of major cortical pathways. J Neurosci 12:1194-1211.

Derer P, Caviness VS, Sidman RL (1977) Early cortical histogenesis in the primary olfactory cortex of the mouse. Brain Res 123:27-40.

Edwards MA, Yamamoto M, Caviness VS (1990) Organization of radial glia and related cells in the developing murine CNS. An analysis based upon a new monoclonal antibody marker. Neuroscience 36:121-144.

Fentress JC, Stanfield BB, Cowan WM (1981) Observations on the development of the striatum in mice and rats. Anat Embryol (Berl) 163:275-298.

Fishell G (1995) Striatal precursors adopt cortical identities in response to local cues. Development 121:803-812.

Fishell G, Mason CA, Hatten ME (1993) Dispersion of neural progenitors within the germinal zones of the forebrain. Nature 362:636-638.

Gadisseux J-P, Evrard P, Misson JP, Caviness VS (1989) Dynamic structure of the radial glial fiber system of the developing murine cerebral wall. An immunocytochemical analysis. Dev Brain Res 50:55-67.

Gadisseux J-P, Kadhim HJ, van den Bosch de Aguilar P, Caviness VS, Evrard P (1990) Neuron migration within the radial glial fiber system of the developing murine cerebrum: and electron microscopic autoradiographic analysis. Dev Brain Res 52:39-56.

Gray GE, Leber SM, Sanes JR (1990) Migratory patterns of clonally related cells in the developing central nervous system. Experientia 46:929-940

Halliday AL, Cepko CL (1992) Generation and migration of cells in the developing striatum. Neuron 9:15-26.

Hatten M (1990) Riding the glial monorail: a common mechanism for glial-guided neuronal migration in different regions of the developing mammalian brain. Trends Neurosci 13:179-184.

Hinds JW, Angevine JB (1965) Autoradiographic study of histogenesis in the area pyriformis and claustrum of the mouse. Anat Rec 151:456-457.

Honig MG (1993) DiI labelling. Neurosci Prot 16:1-20.

Honig MG, Hume RI (1986) Fluorescent carbocyanine dyes allow living neurons of identified origin to be studied in long-term cultures. J Cell Biol 103:171-187.

Honig MG, Hume RI (1989) DiI and DiO: versatile fluorescent dyes for neuronal labelling and pathway tracing. Trends Neurosci 12:333-341.

Johnston JG, Fishell G, Krushel LA, van der Kooy D (1991) The development of striatal compartmentalization: the role of mitotic and postmitotic events. In: The basal ganglia III (Bernardi G, Carpenter MB, Di Chiara G, Morelli M, Stanzioni P, eds), pp 13-20. New York: Plenum.

Kishi K (1987) Golgi studies on the development of granule cells of the rat olfactory bulb with reference to migration in the subependymal layer. J Comp Neurol 258:112-124.

Kishi K, Peng JY, Kakuta S, Murakami K, Kuroda M, Yokota S, Hayakawa S, Kuge T, Asayama T (1990) Migration of subependymal cells, precursors of the granule cells of the rat olfactory bulb, with reference to the arrangement of the radial glial fibers. Arch Histol Cytol 53:219-226.

Krushel LA, Johnston JG, Fishell G, Tibshirani R, van der Kooy D (1993) Spatially localized neuronal cell lineages in the developing mammalian forebrain. Neuroscience 53:1035-1047.
Lammers GJ, Grinbau AAM, ten Donkelaar HJ (1980) Neurogenesis in the basal forebrain in the chinese hamster (Cricetus griseus). II. Site of neuron origin: morphogenesis of the ventricular ridges. Anat Embryol (Berl) 158:193-211.

Liu F-C, Graybiel AM (1992) Transient calbindin- $\mathrm{D}_{28 \mathrm{~K}}$-positive systems in the telencephalon: ganglionic eminence, developing striatum and cerebral cortex. J Neurosci 12:674-690.

Luskin MB (1993) Restricted proliferation and migration of postnatally generated neurons derived from the forebrain subventricular zone. Neuron 11:173-189.

Luskin MB, Pearlman AL, Sanes JR (1988) Cell lineage in the cerebral cortex of the mouse studied in vivo and in vitro with a recombinant retrovirus. Neuron 1:635-647.

Mathis JM, Simmons DM, He LW, Swanson LW, Rosenfeld MG (1992) Brain-4: a novel mammalian POU domain transcription factor exhibiting restricted brain-specific expression. EMBO J 11:2551-2561.

Misson JP, Edwards MA, Yamamoto M, Caviness VS (1988) Identification of radial glial cells within the developing murine central nervous system: studies based upon a new immunohistochemical marker. Dev Brain Res 44:95-108.

Misson J-P, Austin CP, Takahashi T, Cepko CL, Caviness VS (1991) The alignment of migrating neural cells in relation to the murine neopallial radial glial fiber system. Cereb Cortex 1:221-229.

New DAT (1990) Introduction. In: Postimplantation mammalian embryos. A practical approach (Copp AJ, Cockroft DL, eds), pp 1-14. New York: Oxford UP.

Nieuwenhuys R (1972) Topological analysis of the brain stem of the lamprey Lampetra fluviatilis. J Comp Neurol 145:165-178.

Nowakowski RS, Rakic P (1979) The mode of neuron migration to the hippocampus: a Golgi and electron microscopic analysis in fetal rhesus monkey. J Neurocytol 8:679-718.

O'Rourke NA, Dailey ME, Smith SJ, McConnell SK (1992) Diverse migratory pathways in the developing cerebral cortex. Science 258:299-302

O'Rourke NA, Sullivan DP, Kaznowski CE, Jacobs AA, McConnell SK (1995) Tangential migration of neurons in the developing cerebral cortex. Development 121:2165-2176.

Pinto-Lord MC, Evrard P, Caviness VS (1982) Obstructed neuronal migration along radial glial fibers in the neocortex of the reeler mouse: a Golgi-EM analysis. Dev Brain Res 4:379-393.

Porteus MH, Bulfone A, Liu JK, Puelles L, Lo L-C, Rubenstein JLR (1994) DLX-2, MASH-1, and MAP-2 expression and bromodeoxyuridine incorporation define molecularly distinct cell populations in the embryonic mouse forebrain. J Neurosci 14:6370-6383.

Price J, Thurlow L (1988) Cell lineage in the rat cerebral cortex: a study using retroviral-mediated gene transfer. Development 104:473-482.

Price M, Lemaistre M, Pischetola M, Di Lauro R, Duboule D (1991) A mouse gene related to Distal-less shows a restricted expression in the developing forebrain. Nature 351:748-751.

Puelles L, Rubenstein JLR (1993) Expression patterns of homeobox and other putative regulatory genes in the embryonic mouse forebrain suggest a neuromeric organization. Trends Neurosci 16:472-479.

Rakic P (1971) Guidance of neurons migrating to the fetal monkey neocortex. Brain Res 3:471-476.

Rakic P (1972) Mode of cell migration to the superficial layers of fetal monkey neocortex. J Comp Neurol 145:61-84.

Rakic P (1985) Contact regulation of neuronal migration. In: The cell in contact: adhesions and junctions as morphogenetic determinants (Edelmann GM, Thiery J-P, eds), pp 67-91. Cambridge: Neuroscience Research Foundation.

Rakic P (1988) Specification of cerebral cortical areas. Science 241:170-176.

Rakic P (1990) Principles of neural cell migration. Experientia 46:882-891.

Reid CB, Liang I, Walsh C (1995) Systematic widespread clonal organization in cerebral cortex. Neuron 15:299-310.

Schmechel DE, Rakic P (1979) A Golgi study of radial glial cells in developing monkey telencephalon: morphogenesis and transformation into astrocytes. Anat Embryol (Berl) 156:115-152.

Sidman RL, Angevine JB (1962) Autoradiographic analysis of time of origin of nuclear versus cortical components of mouse telencephalon. Anat Rec 142:326-327.

Smart IHM (1976) A pilot study of cell production by the ganglionic eminences of the developing mouse brain. J Anat 121:71-84. 
Smart IHM, Smart M (1977) The location of nuclei of different labelling intensities in autoradiographs of the anterior forebrain of postnatal mice injected with $\left[{ }^{3} \mathrm{H}\right]$ thymidine on the eleventh and twelfth days post-conception. J Anat 123:515-525.

Smart IHM, Sturrock RR (1979) Ontogeny of the neostriatum. In: The neostriatum (Divac I, Öberg RG, eds), pp 127-146. Oxford: Pergamon.

Stensaas LJ, Gilson BC (1972) Ependymal and subependymal cells of the caudo-pallial junction in the lateral ventricle of the neonatal rabbit. Z Zellforsch Mikrosk Anat 132:297-322.

Stewart GR, Pearlman AL (1987) Fibronectin-like immunoreactivity in the developing cerebral cortex. J Neurosci 7:3325-3333.

Tan S-S, Faulkner-Jones B, Breen SJ, Walsh M, Bertram JF, Reese BE (1995) Cell dispersion patterns in different cortical regions studied with an X-inactivated transgenic marker. Development 121:1029-1039.

Valverde F (1970) The Golgi method. A tool for comparative structural analyses. In: Contemporary research methods in neuroanatomy (Nauta WJH, Ebbesson SOE, eds), pp 12-31. New York: Springer.

Valverde F (1993) The rapid Golgi technique for staining CNS neurons. Light microscopy. Neurosci Prot 1:1-9.
Valverde F, Santacana M (1994) Development and early postnatal maturation of the primary olfactory cortex. Dev Brain Res 80:96-114.

Valverde F, Facal-Valverde MV, Santacana M, Heredia M (1989) Development and differentiation of early generated cells of sublayer VIb in the somatosensory cortex of the rat: a correlated Golgi and autoradiographic study. J Comp Neurol 290:118-140.

Valverde F, De Carlos JA, López-Mascaraque L (1995a) Time of origin and early fate of preplate cells in the cerebral cortex of the rat. Cereb Cortex 5:412-422.

Valverde F, López-Mascaraque L, Santacana M, De Carlos JA (1995b) Persistence of early-generated neurons in the rodent subplate: assessment of cell death in neocortex during the early postnatal period. J Neurosci 15:5014-5024.

Walsh C, Cepko CL (1988) Clonally related cortical cells show several migration patterns. Science 241:1342-1345.

Walsh C, Cepko CL (1992) Widespread dispersion of neuronal clones across functional regions of the cerebral cortex. Science 255: $434-440$. 